Short Note

\title{
A note on Northern Marche seismicity: new focal mechanisms and seismological evidence
}

\author{
Stefano Santini \\ Istituto di Fisica dell'Università di Urbino, Italy
}

\begin{abstract}
A geodynamic interpretation of the Northern Marche region is difficult, the zone being characterized by complex structures which cannot be defined in the form of a simple, standard model. It is unquestionable that the geodynamic setting, whatever it is, bears a strong influence on the seismic hazard assessment of a region, and this is the background reason for the present note. In order to obtain a more detailed picture of seismological evidence in this zone, 11 new fault plane solutions of crustal events with $2.9<M<4.3$ were calculated, using data recorded by the national seismic network of the Istituto Nazionale di Geofisica e Vulcanologia in the period 1990-2000. The aim is to add local information to the previous studies by Frepoli and Amato (1997, 2000). A possible result of this new study is the division of the Northern Marche region into three areas with different focal mechanism categories: the inner area of the Apenninic belt, the Adriatic on-shore and the Adriatic off-shore. This note is intended to be a contribution to update seismological evidence in the Northern Marche region.
\end{abstract}

Key words focal mechanisms - Northern Apennines Adriatic off-shore - seismological evidence

\section{Introduction}

For the Northern Apennines, available data consistently indicate active extension in the axial zone of the chain, where the main active

Mailing address: Prof. Stefano Santini, Istituto di Fisica dell'Università di Urbino, Via S. Chiara 27, 61029 Urbino, Italy; e-mail: santini@ fis.uniurb.it structures consist of border faults to a series of NW-SE oriented intramontane basins (Lunigiana, Garfagnana, Mugello, Casentino, high Tiber Valley; e.g., Galadini et al., 2001). A general agreement exists on the fact that a roughly NE-SW oriented minimum stress axis $\left(\sigma_{3}\right)$ is dominant in this part of the orogen (Borghini et al., 2000).

In the studied rectangular area (outer Northern Apennines and related Adriatic off-shore; fig. 1), thrust tectonics has been widely documented by field surveys and by the interpretation of seismic reflection lines and deep wells (e.g., Bally et al., 1986; Barchi et al., 1998). 


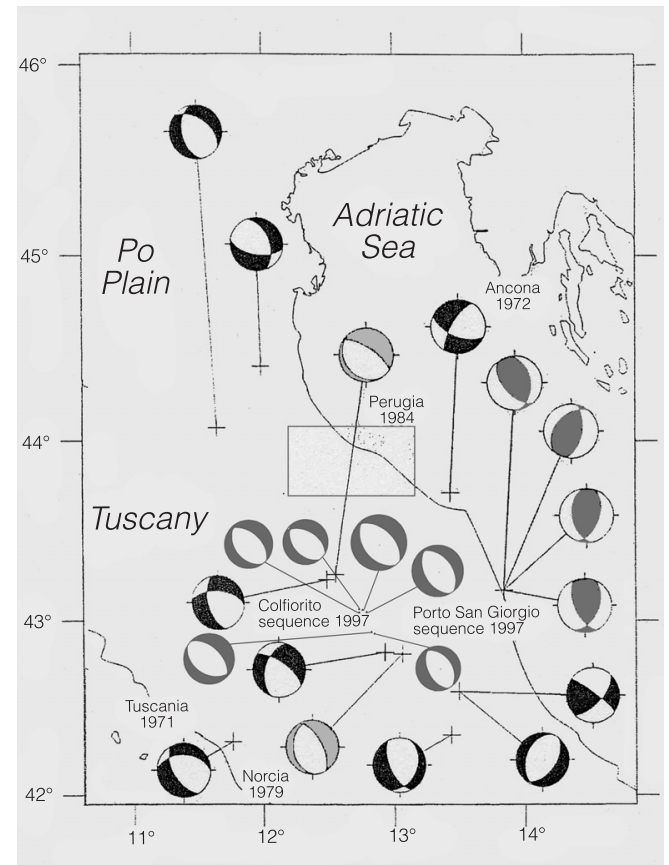

Fig. 1. Fault-plane solutions from Gasparini et al. (1985) (in black), CMT solutions (in light grey), solutions of the four largest events of the Porto San Giorgio sequence of July 1987 from Riguzzi et al. (1989) and of the six largest events of the Colfiorito sequence of September-October 1997 from Santini et al. (2003) (dark grey), and the studied area (in the box) of the Northern Marche region.
On-shore, available field data show that the most important evidence of active tectonics in the studied area is a well documented and generalised Pleistocene uplift (e.g., Dramis, 1992; Borraccini et al., 2002).

The studied area is the locus of a moderate yet significant - tectonic activity, as also witnessed by historical and instrumental seismicity $\left(I_{\max }=\right.$ IX MCS; $M_{\max }=6$; Gruppo di Lavoro CPTI, 1999; Frepoli and Amato, 2000). The sources of these earthquakes are not well known (Galadini et al., 2000) and the possible existence and size of currently silent sources is a matter of study (Valensise and Pantosti, 2001).

\section{Seismic data}

Many focal mechanisms of moderate events with magnitudes ranging between 4.0 and 5.8 have been determined for the Northern Apennines. The available fault-plane solutions of the period 1939-1980, calculated from arrival times and polarities read from seismic bulletins, were reported by Gasparini et al. (1985): the best focal mechanisms are shown in fig. 1 as selected by Zoback (1992), which used $P$ and $T$ axes to divide the data into five main stress regime categories and an unknown category when the data provide no information on relative stress magnitudes (see table I).

Table I. Fault Plane Solutions (FPS) categories of Zoback (1992) used for classification of events shown in fig. 4.

\begin{tabular}{ccccc}
\hline \hline \multicolumn{2}{c}{ Plunges of axes $(\mathrm{pl})$} & $\begin{array}{c}\text { FPS categories by } \\
\text { Zoback (1992) }\end{array}$ & $\begin{array}{c}\text { Figure 4 notation } \\
\text { (label color) }\end{array}$ & Legenda \\
\cline { 1 - 3 }$P$ & $T$ & $\mathrm{NF}$ & blue labels & normal-fault \\
$\mathrm{pl} \geq 52^{\circ}$ & $\mathrm{pl} \leq 35^{\circ}$ & $\mathrm{NS}$ & blue labels & with small-slip-component \\
$40^{\circ} \leq \mathrm{pl} \leq 52^{\circ}$ & $\mathrm{pl} \leq 20^{\circ}$ & $\mathrm{SS}$ & red labels & strike-slip \\
$\mathrm{pl}<40^{\circ}$ & $\mathrm{pl} \leq 20^{\circ}$ & $\mathrm{SS}$ & red labels & strike-slip \\
$\mathrm{pl} \leq 20^{\circ}$ & $\mathrm{pl}<40^{\circ}$ & $\mathrm{TF}$ & green labels & thrust-fault \\
$\mathrm{pl} \leq 35^{\circ}$ & $\mathrm{pl} \geq 52^{\circ}$ & $\mathrm{TS}$ & green labels & with small-slip-component \\
$\mathrm{pl} \leq 20^{\circ}$ & $40^{\circ} \leq \mathrm{pl} \leq 52^{\circ}$ & black labels & unknown category \\
others & others & $\mathrm{UC}$ & &
\end{tabular}


The figure displays also two Centroid Moment Tensor (CMT) solutions of the Norcia (1979) and Perugia (1984) earthquakes, the focal mechanisms of four events of the Porto San Giorgio seismic sequence of July 1987 (Riguzzi et al., 1989) and the focal mechanisms of six events of the Colfiorito seismic sequence of SeptemberOctober 1997 (Santini et al., 2003). The two CMT solutions show an evident normal-fault regime along the portion of the Apenninic belt, while the strike-slip solution of the Ancona (1972) event, shows a compressional axis $(P)$ with ENE-WSW orientation (Frepoli and Amato, 1997).

The only events in previous studies suggesting an evident active compression along the outer part of the Apenninic belt in the Northern Marche occurred on January 26, 1990, and December 15,1991 , as recolored in dark grey in fig. 2 by Frepoli and Amato (1997).

The earthquakes analyzed in this study are located in the Northern Marche from $43^{\circ}$ to $44^{\circ} \mathrm{N}$ and from $12^{\circ}$ to $13.5^{\circ} \mathrm{E}$ (table II). Arrival times and polarities were accurately re-picked from digital seismic waveforms recorded by the seismic network of the INGV in the period 1990-2000.

The duration magnitudes $M_{d}$ of these events range between 3.0 and 4.2. The smaller events are not considered because their mechanism cannot be calculated with good accuracy due to the lack of off-shore seismograph stations: therefore it is advisable to consider magnitudes greater than 3-3.5. The locations of considered

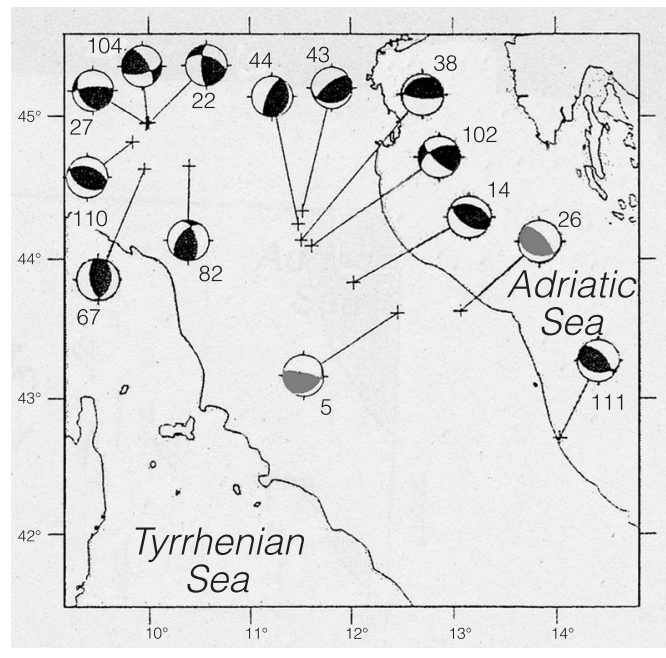

Fig. 2. Thrust-fault solutions from Frepoli and Amato (1997): the solutions of seismic events which occurred in the studied area are recolored in dark grey.

Table III. Velocity model adopted for focal mechanism computation.

\begin{tabular}{cc}
\hline \hline Velocity $(\mathrm{km} / \mathrm{s})$ & Depth $(\mathrm{km})$ \\
\hline 5.7 & $0-12$ \\
6 & $12-18$ \\
6.2 & $18-26$ \\
6.7 & $26-35$ \\
7.5 & $35-$ \\
\hline
\end{tabular}

Table II. Parameters of the seismic events whose epicentres and focal mechanisms are shown in fig. 4.

\begin{tabular}{c|ccccccc|ccrcc}
\hline \hline Label & Year & Month & Day & $\begin{array}{c}\text { Lat } \\
\left({ }^{\circ}\right)\end{array}$ & $\begin{array}{c}\text { Long } \\
\left({ }^{\circ} \mathrm{E}\right)\end{array}$ & $\begin{array}{c}\text { Depth } \\
(\mathrm{km})\end{array}$ & $\mathrm{M}_{d}$ & Strike & Dip & Rake & $\begin{array}{c}\text { rms } \\
(\mathrm{s})\end{array}$ & $F$ \\
\hline 1 & 1990 & August & 27 & 44.02 & 13.177 & 5.0 & 3.9 & $115^{\circ}$ & $50^{\circ}$ & $0^{\circ}$ & 0.10 & 0.00 \\
2 & 1991 & November & 22 & 43.842 & 12.062 & 5.9 & 3.0 & $165^{\circ}$ & $60^{\circ}$ & $-70^{\circ}$ & 0.02 & 0.03 \\
3 & 1996 & June & 28 & 43.769 & 12.995 & 27.5 & 3.4 & $155^{\circ}$ & $40^{\circ}$ & $110^{\circ}$ & 0.16 & 0.12 \\
4 & 2000 & February & 22 & 43.79 & 12.083 & 8.0 & 3.0 & $265^{\circ}$ & $65^{\circ}$ & $-120^{\circ}$ & 0.01 & 0.13 \\
5 & 2000 & May & 5 & 44.014 & 13.192 & 5.0 & 4.1 & $195^{\circ}$ & $25^{\circ}$ & $30^{\circ}$ & 0.25 & 0.20 \\
6 & 2000 & June & 25 & 43.886 & 13.147 & 5.0 & 3.5 & $130^{\circ}$ & $90^{\circ}$ & $-50^{\circ}$ & 0.16 & 0.18 \\
7 & 2000 & June & 27 & 43.883 & 13.200 & 5.0 & 3.4 & $115^{\circ}$ & $85^{\circ}$ & $40^{\circ}$ & 0.06 & 0.14 \\
8 & 2000 & August & 1 & 43.929 & 12.318 & 5.0 & 4.2 & $160^{\circ}$ & $70^{\circ}$ & $130^{\circ}$ & 0.02 & 0.10 \\
9 & 2000 & December & 27 & 43.678 & 12.245 & 5.0 & 3.2 & $115^{\circ}$ & $30^{\circ}$ & $-80^{\circ}$ & 0.13 & 0.12 \\
\hline
\end{tabular}




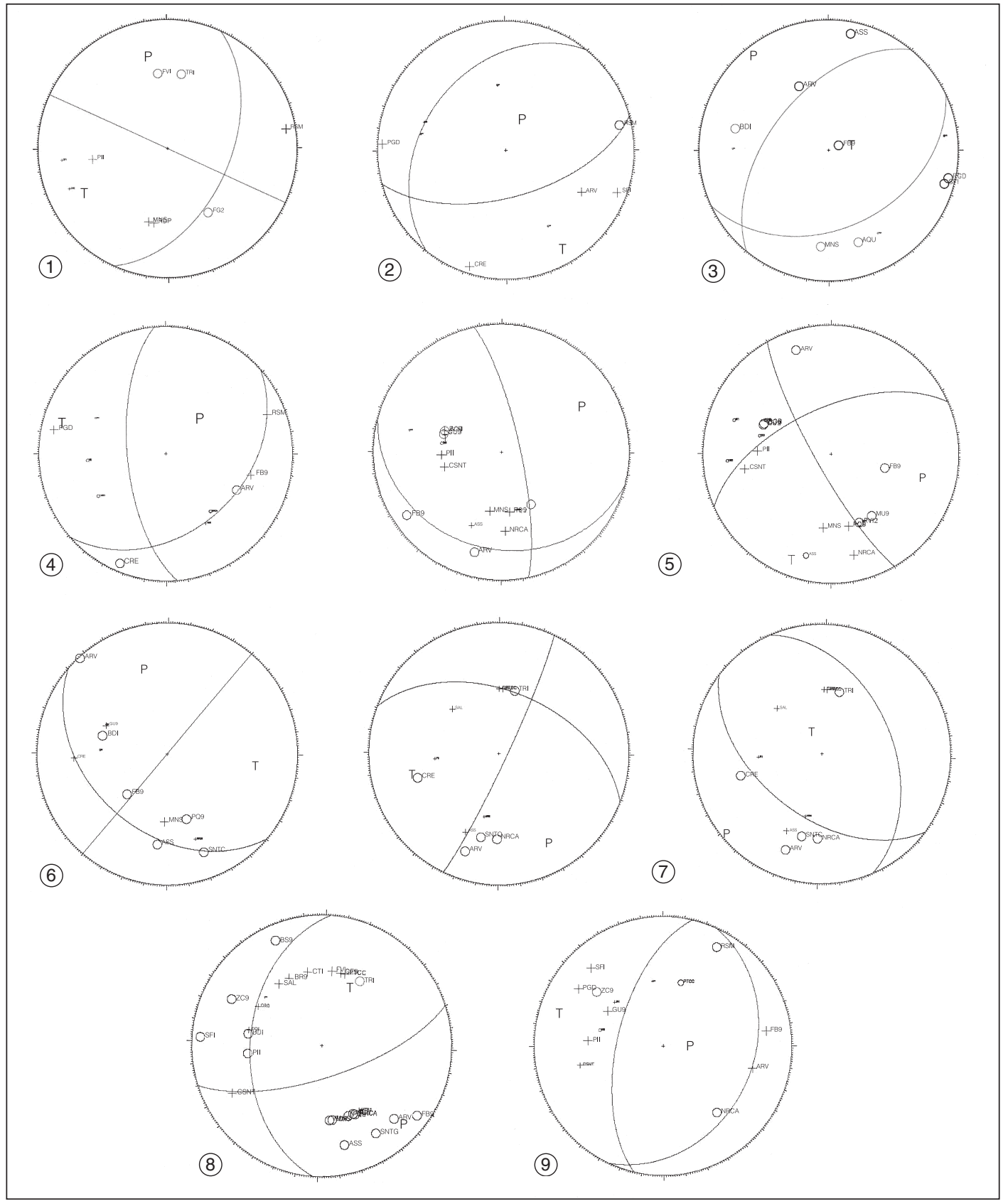

Fig. 3. Lower hemisphere, equal-area projection of the 11 selected fault plane solution presented in this study. Compression and dilatation polarities are indicated with crosses and circles, respectively. The 9 focal mechanisms of fig. 4 are the first solutions; in the case of double solutions (5 and 7), the second solutions with a worse stability are shown. 
events were verified with the computer program HYPOINVERSE (Klein, 1989) using the velocity structure reported in table III.

Good values of rms residuals were obtained for most analyzed earthquakes; in particular the rms values of locations have residuals below $0.25 \mathrm{~s}$; furthermore, a misfit of polarity quality factor $(F)$ was below 0.20 . The fault plane solutions were calculated with the program FPFIT (Reasenberg and Oppenheimer, 1985) and the 11 fault plane solutions were obtained with more than eight polarities.

\section{New focal mechanisms}

This classification is founded on the assumption that the earthquake focal mechanisms reflect the state of stress of the Northern Marche region, implying that the $P$ - and $T$-axes, to a first approximation, correspond to the principal stress axes $\sigma_{1}$ and $\sigma_{3}$, respectively.

Figure 3 shows fault plane solutions for 9 events which occurred in the Northern Marche from 1990 to 2000. The multiple solutions are due both to the low weight of some polarities and to the low azimuthal coverage of data on the focal sphere. In fig. 4 the solutions with the smaller uncertainties were chosen, represented by the first solutions of the 9 focal mechanisms of fig. 3 ; if one considers the alternative solutions, the tectonic setting does not change much.

The 9 first solutions of fig. 3 are divided as follows:

- three solutions (labels 2, 4 and 9) belong to the pure normal-fault category (NF);

- two solutions (labels 3 and 5) belong to the pure thrust-fault category (TF);

- one solution (label 8) belongs to the thrustfault with small strike-slip category (TS);

- three solutions (labels 1, 6 and 7) are included in the unknown-stress-field category (UC).

If plunges of the axes of solutions are inside or outside the ranges defined in table I with differences of only one degree these solutions were assigned to the appropriate category: in this case, one solution (label 5) belongs to the thrust-fault with small strike-slip category with a difference of 0.2 degrees, as it is possible to see in table II.

The eastern part of the examined area was also affected by a few historical events of magnitude larger than 5.5. The estimated sources of these events are shown in fig. 4. The northernmost box (west of Pesaro) represents the source of the Coriano earthquake (December 25, 1786;

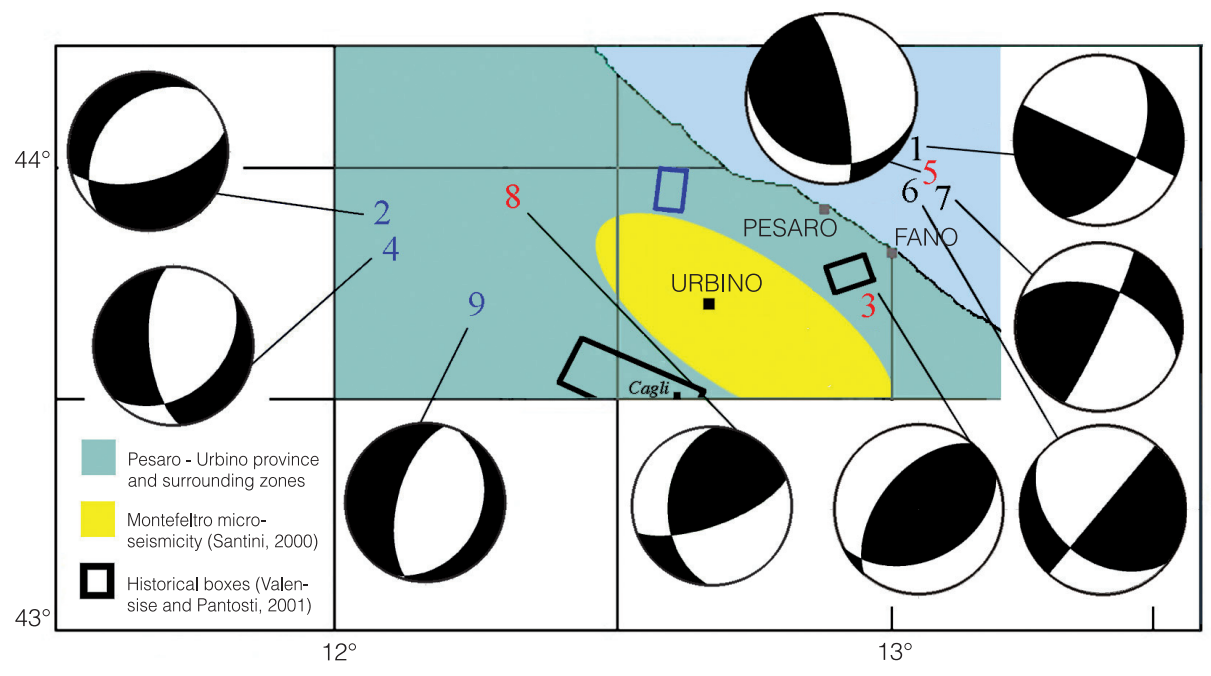

Fig. 4. Epicentre location and focal mechanisms of seismic events listed in table II. Fault Plane Solution (FPS) categories refer to Zoback (1992; table I). Historical boxes after Valensise and Pantosti (2001). 

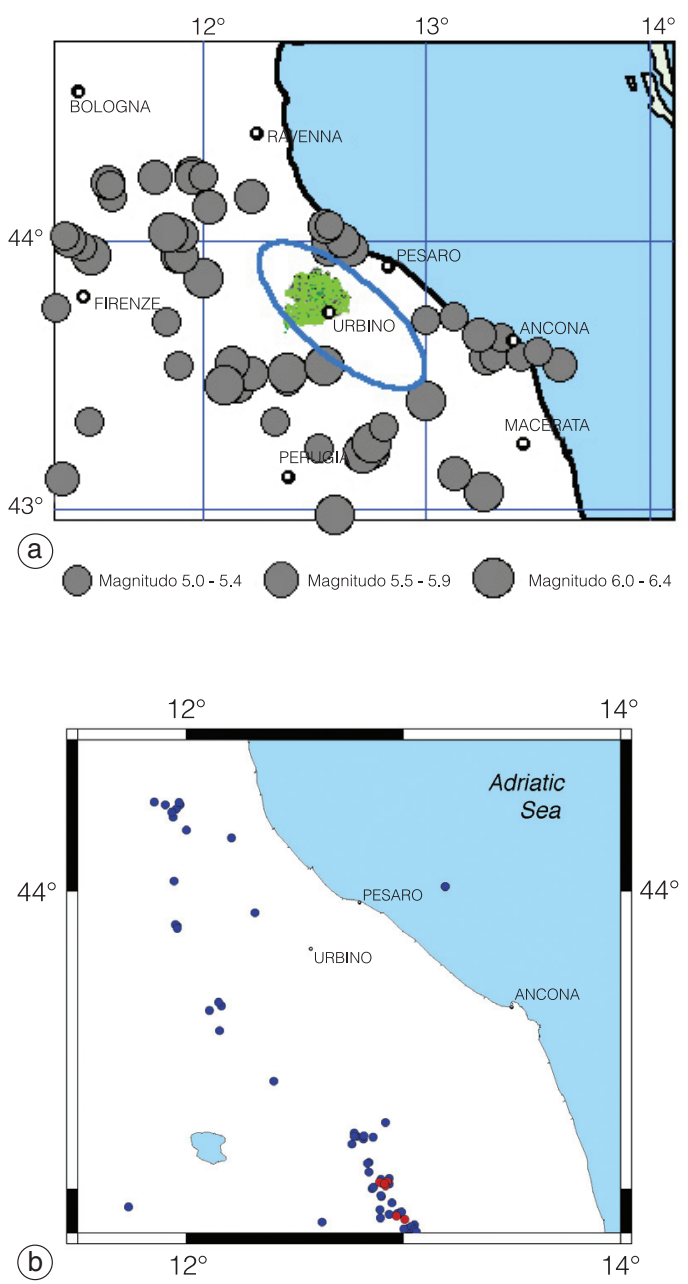

Fig. 5a,b. a) Historical seismicity examined by Santini (2000), from Boschi et al. (1997) and Gruppo di Lavoro CPTI (1999); The Montefeltro area (green zone) is characterized by limited values in terms of intensity and frequency (blue ellipse). b) Epicentres of seismic events with magnitude $\geq 4$ recorded by the national seismic network of INGV from year 1990 to 2003 (blue circles with magnitude $<5$ and red circles with magnitude $\geq 5$ ).

$\left.43.98^{\circ} \mathrm{N} ; 12.58^{\circ} \mathrm{E}\right)$, an event of intensity $I_{0}=$ VIII and equivalent magnitude $M_{e}=5.5$ (Gruppo di Lavoro CPTI, 1999). This source is derived by the analysis of the isoseismal map produced by Guidoboni and Ferrari (1986); it strikes $20^{\circ} \pm 15^{\circ}$ and is $5.6 \mathrm{~km}$ long and $5.2 \mathrm{~km}$ wide.

The two other sources, instead, are exclusively derived from intensity data by applying the method proposed by Gasperini et al. (1999), as the quality of the obtained solution allowed the representation of the source by an oriented rectangular box (Valensise and Pantosti, 2001). The box south-west of Fano $\left(43.71^{\circ} \mathrm{N}\right.$; $12.97^{\circ} \mathrm{E}$ ) corresponds to the September 21, 1897 earthquake $\left(I_{0}=\right.$ VII and $M_{e}=5.4$; Gruppo di Lavoro CPTI, 1999) and strikes $73^{\circ} \pm 48^{\circ}$. The southernmost box represents the seismic source for the Cagli event $\left(43.59^{\circ} \mathrm{N} ; 12.51^{\circ} \mathrm{E}\right)$ which occurred on June 3, $1781\left(I_{0}=\right.$ IX-X and $M_{e}=6.2$; Gruppo di Lavoro CPTI, 1999). This source strikes $118^{\circ} \pm 17^{\circ}$.

\section{Conclusions}

The Northern Apennine chain was described as a tectonic belt characterized by extension (e.g., Lavecchia, 1988; Decandia et al., 1998). General agreement exists on the fact that a NE-SW oriented minimum stress axis $\left(\sigma_{3}\right)$ is dominant in the axial zone of the chain (Mariucci et al., 1999; Boncio et al., 2000). A possible result of this study is the division of the Northern Marche region into three areas with different seismological evidences:

- the inner area of the Apenninic belt, which is caracterized by extension;

- the Adriatic on-shore, which shows evidence of active compression;

- the Adriatic off-shore, which shows not very clear evidence of active compression.

In the extensional area, the $T$-axes of normal solutions (2, 4 and 9 in fig. 4) do not have a homogeneous orientation, while in the compressional area the $P$-axes of thrust solutions ( 3 and 8 in fig. 4) have a dominant NW-SE direction (in agreement with compressive stress regime mapped by Montone et al. (1999) in northern surrounding zones of the Northern Marche).

Finally, the Adriatic off-shore zone shows not clear seismological evidence of nevertheless possible active compression; on the other hand no earthquake with magnitude $\geq 5$ occurred during historical times in the off-shore zone of the Northern Marche region (fig. 5a,b). 


\section{Acknowledgements}

I am grateful to Michele Dragoni and another anonymous referee for their reviews, which improved the paper. I thank Gianluca Valensise for his critical and constructive comments on the scientific starting point of this study, and Alessandro Amato for his encouragement with the present note. This research has been financially supported by «COFIN 2001» of Ministero dell' Istruzione, dell'Università e della Ricerca (MIUR).

\section{REFERENCES}

BALly, A.W., L. Burbi, C. COOPER and R. GHELARDONI (1986): Balanced sections and seismic reflection profiles across the Central Apennines, Mem. Soc. Geol. Ital., 35, 257-310.

BARCHI, M.R., G. Minelli and G. PIALLI (1998): The CROP 03 profile: a synthesis of results on deep structures of the Northern Apennines, Mem. Soc. Geol. Ital., 52, 383-400.

Boncio, P., F. Brozzetti and G. LAVEcchia (2000): Architecture and seismotectonics of a regional lowangle normal fault zone in Central Italy, Tectonics, 19, 1038-1055.

Borghini, G., M. Bernini and G. PAPANi (2000): Individuazione e mappatura di faglie attive e/o strutture sismogenetiche in Appennino nord-occidentale, in Le Ricerche del GNDT nel Campo della Pericolosità Sismica (1996-1999), edited by F. GALADINI, C. MELETTI and A. REBEZ, 143-148.

Borraccini, F., M. DE Donatis, D. Di BuCCI, S. MaZzoli, A. Megna, O. Nesci, S. Santini, D. Savelli, M. TramontanA and P. Triggiani (2002): Analisi della tettonica quaternaria nel basso bacino del F. Metauro (Marche settentrionali) e nell'adiacente offshore adriatico attraverso l'integrazione di dati sismici, geomorfologici, stratigrafici e strutturali, Studi Geologici Camerti, 2, 29-43.

Boschi, E., E. Guidoboni, G. Ferrari, G. VAlensise and P. GASPERINI (Editors) (1997): Catalogo dei Forti Terremoti in Italia dal 461 a.C. al 1990 (ING, Roma SGA, Bologna), vol. 2, pp. 644.

DeCANDiA, F.A., A. LAZZAROTTO, D. LiOTTA, L. CERNOBORI and R. NICOLICH (1998): The CROP 03 traverse: insights on post-collisional evolution on the Northern Apennines, Mem. Soc. Geol. It., 52, 427-439.

DRAMIS, F. (1992): Il ruolo dei sollevamenti tettonici a largo raggio nella genesi del rilievo appenninico, Studi Geologici Camerti, 1 (special volume), 9-15.

Frepoli, A. and A. Amato (1997): Contemporaneous extension and compression in the Northern Apennines from earthquake fault plane solutions, Geophys. J. Int., 129, 368-388.
Frepoli, A. and A. Amato (2000): Spatial variations in stresses in peninsular Italy and Sicily from background seismicity, Tectonophysics, 317, 109-124.

Galadini, F., C. Meletti and E. VitTori (2000): Stato delle conoscenze sulle faglie attive in Italia: elementi geologici di superficie, in Le Ricerche del GNDT nel Campo della Pericolosità Sismica (1996-1999), edited by F. Galadini, C. Meletti and A. ReBez, 107-136.

Galadini, F., C. Meletti and E. VitToRi (2001): Major active faults in Italy: available surficial data, Neth. J. Geosci. Geol. Mijnbouw, 80, 273-296.

GASPARINI, C., G. IANNACCONE and R. SCARPA (1985): Fault-plane solutions and seismicity of the Italian peninsula, Tectonophysics, 117, 59-78.

GASPERINI, P., F. BERNARDINI, G. VALENSISE and E. BosCHI (1999): Defining seismogenic sources from historical earthquake felt reports, Seismol. Soc. Am. Bull., 89, 94-110.

GRUPPO DI LAVORO CPTI (1999): Catalogo Parametrico dei Terremoti Italiani (ING, GNDT, SGA, SSN), pp. 88.

GUIDOBONI, E. and G. FERRARI (1986): Il Terremoto di Rimini e della Costa Romagnola: 25 Dicembre 1786. Analisi e Interpretazione (SGA), 127-142.

KLEIN, F.W. (1989): HypoINVERSE, a program for Vax computers to solve for earthquake location and magnitude, U.S. Geol. Surv. Open-File Rep., 89-314.

LAVECCHIA, G. (1988): The Tyrrhenian-Apennine system: structural setting and seismotectogenesis, Tectonophysics, 147, 263-296.

MARIUCCI, M.T., A. AMATO and P. MONTONE (1999): Recent tectonic evolution and present stress in the Northern Apennines, Tectonics, 18, 108-118.

Montone, P., A. Amato and S. Pondrelli (1999): Active stress map of Italy, J. Geophys. Res., 104, 25,59525,610 .

REASENBERG, P. and D. OPPENHEIMER (1985): FPFIT, FPPLOT and FPPAGE: FORTRAN computer program for calculating and displaying earthquake fault-plane solutions, U.S. Geol. Surv. Open-File Rep., 85/739, pp.109.

RiguZZI, F., A. TeRTULLIANI and C. GASPARINI (1989): Study of the seismic sequence of Porto San Giorgio: Marche 3 July 1987, Nuovo Cimento C, 12, 453-466.

SANTINI, S. (2000): Montefeltro seismicity: from Serpieri's seismograph to the RSNC seismograph station, Ann. Geofis., 43 (3), 505-517.

SANTINI, S., P. BALDI, M. DRAGONI, A. PiOMBO, S. SALVI, G. SPADA and S. STRAMONDO (2003): Montecarlo inversion of DInSAR data for dislocation modeling: application to 1997 Umbria-Marche seismic sequence (Central Italy), Pure Appl. Geophys. (in press).

VAlensise, G. and D. PANTosti (Editors) (2001): Database of potential sources for earthquakes larger than $M 5.5$ in Italy, Ann. Geofis., 44 (suppl. to n. 4), pp.180 (with CD-ROM)

ZOBACK, M.L. (1992): First- and second-order patterns of stress in the lithosphere: the world stress map project, J. Geophys. Res., 97, 11,703-11,728.

(received April 7, 2003; accepted July 15, 2003) 